\title{
Heavy metals in pastureland soils situated in A Pastoriza (NW Spain) treated with cattle slurry and NPK fertilizers
}

\author{
Metales pesados en suelos de pradera de A Pastoriza (NO España) tratados con purin de \\ vacuno y fertilizantes NPK \\ Metais pesados em solos de pastagem da A Pastoriza (NO Espanha) tratados com chorume \\ de vaca e adubos NPK
}

\section{AUTHORS}

\section{Seco-Reigosa N. ${ }^{1}$}

Fernández-

Sanjurjo M.J. ${ }^{1}$

Núñez-Delgado A. ${ }^{1}$

Cutillas-Barreiro L. ${ }^{2}$

Gómez-Armesto A. ${ }^{2}$

Nóvoa-Muñoz J.C. ${ }^{2}$

Arias-Estévez M. ${ }^{2}$

Álvarez-Rodríguez E. ${ }^{\circledR, 1}$

esperanza.alvarez@ usc.es

@ Corresponding Author

1 Dpto. Edafoloxía e Química Agrícola, Escola Politécnica Superior. Campus de Lugo. Universidade

de Santiago de

Compostela. Avda.

Benigno Ledo s/n. 27002

Lugo, Spain.

${ }^{2}$ Dpto. Bioloxía Vexetal e Ciencia do Solo,

Facultade de Ciencias.

Campus de Ourense.

Universidade de Vigo.

As Lagoas s/n. 32004

Ourense, Spain.
Received: 12.11.2014 | Revised: 29.04.2015 | Accepted: 04.05.2015

\section{ABSTRACT}

In Galicia (NW Spain), pasturelands cover a broad extension and are mainly used to feed cattle. Farms are managed in an intensive manner, using cattle slurry and inorganic fertilizers to increase pasture production, but also increasing risks of heavy metal pollution. In this work we studied the influence of fertilization practices on total concentrations and in-depth distribution of heavy metals and related elements (As, $\mathrm{Cd}, \mathrm{Cr}, \mathrm{Cu}, \mathrm{Mn}, \mathrm{Ni}, \mathrm{Pb}$ and $\mathrm{Zn}$ ) in two forest soils (SN1, SN2) and five pastureland soils (P1-P5) fertilized with cattle slurry and NPK, in a broadly exploded farmland area (A Pastoriza, Lugo). Soils SN2 and P4 were developed over slate, whereas soils SN1, P1, P2, P3 and P5 evolved on Candana quartzite. Forest soils presented acid $\mathrm{pH}$ (4.58-4.68), high Al saturation (75-90\%), and low available $\mathrm{P}$ concentration (4.78-11.96 $\left.\mathrm{mg} \mathrm{kg}^{-1}\right)$, whereas those parameters exhibited better scores in the pastureland soils, due to previous amendment and fertilization practices, thus giving $\mathrm{pH}$ 5.17-7.02, Al saturation $0.58-59.24 \%$, and available P 5.24-42.07 $\mathrm{mg} \mathrm{kg}^{-1}$. Regarding heavy metals, soil depth did not affect significantly to total concentrations, contrary to that happening with parent material, with higher $\mathrm{As}, \mathrm{Cu}, \mathrm{Fe}$, and $\mathrm{Ni}$ concentrations found in soils over slate (possibly due to the presence of pyritic materials). In most cases, heavy metal total concentrations were lower than that considered as reference background levels for soils developed over each of the parent materials, and were always lower than that considered phyto-toxic. In this study, natural soils usually presented heavy metal total contents similar or even higher than that of the fertilized soils (unless $\mathrm{Zn}$ in the P4 pastureland), thus indicating that the spread doses of fertilizers did not influence significantly their concentration levels.

\section{RESUMEN}

En Galicia las praderas ocupan una gran extensión, siendo utilizadas principalmente para la alimentación del ganado vacuno destinado tanto a la producción de leche como de carne. Las granjas se manejan de manera intensiva, utilizando fertilizantes inorgánicos y purín de vacuno para aumentar la producción de pastos. Esta práctica puede aumentar el contenido de metales pesados en el suelo. En este trabajo se estudian las concentraciones totales y la distribución en profundidad de metales pesados y elementos afines ( $\mathrm{As}, \mathrm{Cd}, \mathrm{Cr}, \mathrm{Cu}, \mathrm{Mn}, \mathrm{Ni}, \mathrm{Pb}$ y $\mathrm{Zn}$ ) en dos suelos forestales (SN1, SN2) y en cinco praderas (P1-P5) fertilizadas con purin de vacuno y NPK en una zona con una gran vocación ganadera (A Pastoriza, Lugo). Se pretende conocer el grado de influencia de la fertilización sobre los niveles de estos elementos. Los suelos elegidos se desarrollaron a partir de pizarras (SN2, P4) y de cuarcitas de la Serie de Cándana (SN1, P1, P2, P3, P5). Los suelos forestales presentaron pH ácido (4,58-4,68), elevada saturación del complejo de cambio por Al (75-90\%) y baja concentración de P disponible (4,78-11,96 $\mathrm{mg} \mathrm{kg}^{-1}$ ); estos parámetros mejoran en los suelos de pradera como consecuencia de las enmiendas y fertilizantes aplicados, presentando un $p H$ entre 5,17 y 7,02, una saturación de Al que varía entre 0,58-59,24\% y P disponible entre 5,24 y 42,07 $\mathrm{mg} \mathrm{kg}^{-1}$. En relación con los metales pesados, la profundidad de la muestra no afecta de modo significativo a su concentración total, pero sí el material de partida, presentando concentraciones más elevadas de $\mathrm{Fe}, \mathrm{As}$, Cu y Ni 
los suelos desarrollados sobre pizarras, posiblemente debido a la presencia de materiales piriticos. En la mayoría de los casos, los metales pesados estudiados presentan concentraciones totales inferiores a las establecidas como genéricas para suelos desarrollados sobre los respectivos materiales geológicos, y siempre son menores que los limites considerados fitotóxicos. La fertilización aplicada no parece tener una influencia significativa sobre los contenidos totales de estos elementos, con la excepción del Zn en la pradera P4, ya que los suelos naturales en muchos casos presentan valores similares e incluso superiores a los obtenidos en las parcelas fertilizadas.

\section{RESUMO}

As pastagens ocupam uma grande área na região da Galicia (NO Espanha) destnando-se sobretudo à alimentação de bovinos para produção de leite e carne. As exploraçôes são geridas de forma intensiva, aplicando-se adubos minerais e chorumes com o objetivo de aumentar a produção de pastos. Contudo, esta prática pode aumentar o teor de metais pesados no solo. Neste trabalho, a concentração total e a distribuição em profundidade de metais pesados e elementos associados ( $\mathrm{As}, \mathrm{Cd}, \mathrm{Cr}, \mathrm{Cu}, \mathrm{Mn}, \mathrm{Ni}, \mathrm{Pb}$ e $\mathrm{Zn}$ ) foram estudados em dois solos florestais (SN1, SN2) em cinco talhões (P1-P5) adubados com NPK e chorume de bovino, numa área com uma grande vocação para pecuária (A Pastoriza, Lugo). Teve-se por objetivo principal determinar o grau de influência da fertilização nos teores destes elementos. Os solos selecionados foram desenvolvidos a partir de ardósias (SN2, P4) e quartzitos da Série de Candana (SN1, P1, P2, P3, P5). Os solos florestais apresentavam pH ácido (4,58-4,68), alta saturação de Al (75-90\%) no complexo de troca de e baixa concentração de P disponivel (4,78-11,96 mg kg-1); estes parâmetros melhoram em solos de pastagem, como resultado da calagem e fertilizantes aplicados, apresentando um $p H$ entre 5,17 e 7,02; saturação por Al variando de 0,58 a 59,24\% e P disponível entre 5,24 e 42,07 $\mathrm{mg} \mathrm{kg}^{-1}$. Em relação aos metais pesados, a profundidade da amostra não afetou significativamente a sua concentração total, contrariamente ao que se verificou com o material parental, que apresentou as concentraçóes mais elevadas de $\mathrm{Fe}, \mathrm{As}$, Cu e $\mathrm{Ni}$ nos solos desenvolvidos a partir de ardósias possivelmente devido à presença de materiais piríticos. Na maioria dos casos, os metais pesados estudados apresentaram concentraçôes totais inferiores aos valores geralmente considerados como referência para solos desenvolvidos a partir dos respetivos materiais parentais, sendo sempre inferiores aos valores limite considerados fitotóxicos. Neste estudo, os solos naturais apresentaram valores de metais pesados semelhantes ou mesmo superiores aos dos solos fertilizados (exceto para o Zn na pastagem P4), o que indica que as doses aplicadas de fertilizantes não influenciaram de forma significativa os seus níveis de concentração.

\section{Introduction}

Heavy metals are elements with atomic number above 20 (excluding alkaline and alkalineearth metals) with density $\geq 5 \mathrm{~g} \mathrm{~cm}^{-3}$ when they are in elemental form (Oves et al. 2012). Some metalloids, such as As, are frequently included in this group due to having similar chemical characteristics and environmental behavior (Chen et al. 1999). Heavy metals entering and circulating into the biosphere constitute a matter of growing environmental concern (Facchinelli et al. 2001; Solgi et al. 2012). Some of them are essential for living organisms, but may cause severe problems when present in high concentrations (Khan et al. 2010; Sun et al. 2010). Prolonged exposition to high Cd levels may cause kidney failure, hypertension and cancer (Nordberg et al. 2002; Turkdogan et al. 2003). Cr is associated to thyroid, blood and coronary affectations, whereas $\mathrm{Mn}$ and $\mathrm{Cu}$ have been related with neurologic illness (Dieter et al. 2005). Ni may cause cardiac and breathing troubles, $\mathrm{Zn}$ can affect the immune system (Muhammad et al. 2011), As is related with skin cancer and neuropathies (Żukowska and Biziuk 2008), and Pb with nervous system, circulatory and enzymatic affectations (Zhang et al. 2012a). 
Although natural geochemical processes can give high heavy metal concentration in soils, it may be caused by different anthropic activities (mining, industry, agriculture, waste management, etc.), resulting in soil degradation and productivity loss (Khan 2013). Among agricultural activities, slurry and inorganic fertilizers spreading may lead to increased heavy metal concentrations in soils (Sager 2007; Moral et al. 2008; Jia et al. 2010; Zhang et al. 2012b), then in plants, and subsequent transfer to the food chain (Sun et al. 2010).

An extension of 433,458 ha is devoted to pastureland in Galicia (IGE 2012), needing cattle slurry and inorganic fertilizers spreading to minimize nutrients deficit, thus implying risks of heavy metal accumulation and decrease of pasture quality (Dong et al. 2011).

In view of that, in this work we determine total content and distribution of $\mathrm{As}, \mathrm{Cr}, \mathrm{Cu}, \mathrm{Fe}, \mathrm{Mn}$, $\mathrm{Ni}, \mathrm{Pb}$ and $\mathrm{Zn}$ (depths $0-5,5-10$ and $10-20 \mathrm{~cm}$ ) in pastureland soils from an intensive farming area (A Pastoriza, Lugo), where cattle slurry and inorganic fertilizer are spread, also comparing with the levels corresponding to forest soils from the same area, in order to distinguish between lithological and anthropogenic origin.

\section{Material and Methods}

The study area was placed in A Pastoriza (Lugo province, Galicia, NW Spain). Mean annual precipitation and temperature are between 950$1350 \mathrm{~mm}$, and between $10-12^{\circ} \mathrm{C}$, respectively. Five pastureland plots (P1-P5) and two forest plots (SN1, on Pinus insignis, and SN2, on Eucalyptus globulus) were performed. Surface was around $500 \mathrm{~m}^{2}$ for all plots. The pastureland plots were located in an area with almost no slope, whereas the forest plots had longitudinal slope equivalent to $30 \%$. The forest soils were classified as Umbrisol (WRB 2006). The pastureland plots were devoted to this soil use for more than 30 years. They included seeded species (Lolium multiflorum Lam. and Trifolium pretense L.) and spontaneous species, usually dominant in Galician meadows (Mosquera et al. 2000; Álvarez et al. 2010, 2012). These soils are usually spread with cattle slurry and NPK fertilizers, without systematic patter of application. Any case, usual yearly doses in the area are: $100 \mathrm{~m}^{3}$ ha $^{-1}$ for cattle slurry and $1000 \mathrm{~kg} \mathrm{ha}^{-1}$ for NPK 8:24:16. The dominant parent materials were Candana quartzite (SN1, P1, P2, P3 and P5 plots) and slate (SN2 and P4 plots).

Soils were sampled at three depths in each plot $(0-5,5-10$ and $10-20 \mathrm{~cm})$ to study total contents of heavy metals, whereas general characteristics were determined on $0-20 \mathrm{~cm}$ depth samples. Samples were taken in October 2013, when 5 transects were delimited in each plot and 5 sub-samples were taken at each depth $(20 \mathrm{~m}$ longitudinal separation between subsequent points), in a zigzag manner. Subsamples were used to perform one composite sample for each depth and transect, giving a total number of 5 composite samples for each depth and plot. Subsamples were taken by using an open probe (20 $\mathrm{cm}$ depth), then differencing among three sections $(0-5,5-10,10-20 \mathrm{~cm})$ to study heavy metals, whereas undivided samples $(20 \mathrm{~cm})$ were used to study general parameters. Soil samples were oven dried (at $40^{\circ} \mathrm{C}$ ) and sieved through $2 \mathrm{~mm}$ mesh. The $<2 \mathrm{~mm}$ fraction was analyzed for $\mathrm{pH}\left(\mathrm{H}_{2} \mathrm{O}\right)$ and $\mathrm{pH}(\mathrm{KCl})$ (Guitián and Carballas 1976), total $\mathrm{C}$ and $\mathrm{N}$ total (LECO auto-analyzer CNS-2000), available P (Olsen and Sommers 1982), exchangeable cations and effective cation exchange capacity (eCEC) (Peech et al. 1946). Total P, Ca, Al, Fe, As, Cr, $\mathrm{Cu}, \mathrm{Mn}, \mathrm{Ni}, \mathrm{Pb}, \mathrm{Cd}$ and $\mathrm{Zn}$ were determined by $X$ ray fluorescence (USC in-house dispersion spectrophotometer).

Data were statistically treated by using analysis of variance tests and Student's T test, determining the least significant differences, and linear regression, by means of the SPSS software, version 19.0 for Windows. 


\section{Results}

Pastureland soils (P1-P5) showed higher $\mathrm{pH}$ values than that of forest soils in the area ( $\mathrm{SN} 1$ and SN2), especially in the case of P5, and also usually higher available $\mathrm{P}$ concentrations (especially $\mathrm{P} 4$, although being lower in $\mathrm{P} 3$ and $\mathrm{P5})$, as well as for eCEC, and for exchangeable $\mathrm{Ca}$ and $\mathrm{Mg}$ (especially in P5), and lower Al concentration and saturation in the cationic exchange complex (Table 1), this in relation with the previous application of amendments and fertilizers.
Both natural soils here studied (SN1 and SN2) showed $\mathrm{Ca}_{1}$ and a modifiers as per Buol et al. (1975), meaning that $\mathrm{Ca}$ concentration was $<1.5 \mathrm{cmol}_{(+)} \mathrm{kg}^{-1}$ in the cationic exchange complex, and that Al saturation was $>60 \%$. Moreover, soil SN2 presented the $M g_{1}$ modifier, meaning that $\mathrm{Mg}$ cation exchange capacity was $<0.4 \mathrm{cmol}_{(+)} \mathrm{kg}^{-1}$.

Among pastureland soils, P3 presented the lowest values for $\mathrm{pH}$, eCEC, and exchangeable $\mathrm{Ca}$ and $\mathrm{Mg}$, but the highest level for Al saturation (being near alic condition). In the opposite extreme was soil P5.

Table 1. General characteristics of the soils $(0-20 \mathrm{~cm}$ depth). $\mathrm{SN}$ : forest soil; P: pastureland soil

\begin{tabular}{|c|c|c|c|c|c|c|c|}
\hline & SN1 & SN2 & $\mathrm{P} 1$ & $\mathrm{P} 2$ & P3 & P4 & P5 \\
\hline $\mathrm{pH}_{\mathrm{H}_{2} \mathrm{O}}$ & 4.58 & 4.68 & 5.3 & 5.74 & 5.19 & 5.54 & 7.02 \\
\hline $\mathrm{pH}_{\mathrm{kCl}}$ & 3.91 & 4.03 & 4.3 & 4.26 & 3.94 & 4.61 & 6.30 \\
\hline Available $\mathrm{P}\left(\mathrm{mg} \mathrm{kg}^{-1}\right)$ & 4.78 & 11.96 & 18.99 & 37.94 & 5.24 & 42.07 & 8.91 \\
\hline C (\%) & 7.74 & 5.64 & 5.62 & 8.07 & 2.28 & 4.17 & 5.09 \\
\hline N (\%) & 0.58 & 0.41 & 0.50 & 0.75 & 0.19 & 0.41 & 0.42 \\
\hline $\mathrm{Ca}\left(\mathrm{cmol}_{(+)} \mathbf{k g}^{-1}\right)$ & 0.66 & 0.03 & 7.35 & 8.95 & 1.38 & 5.11 & 26.16 \\
\hline $\mathbf{M g}\left(\mathrm{cmol}_{(+)} \mathbf{k g}^{-1}\right)$ & 0.71 & 0.20 & 1.00 & 1.18 & 0.38 & 0.84 & 2.35 \\
\hline $\mathrm{Na}\left(\mathrm{cmol}_{(+)} \mathbf{k g}^{-1}\right)$ & 0.18 & 0.11 & 0.26 & 0.20 & 0.18 & 0.15 & 0.39 \\
\hline $\mathbf{K}\left(\mathrm{cmol}_{(+)} \mathbf{k g}^{-1}\right)$ & 0.56 & 0.35 & 0.52 & 0.69 & 0.58 & 0.44 & 0.73 \\
\hline Al $\left(\mathrm{cmol}_{(+)} \mathbf{k g}^{-1}\right)$ & 6.62 & 6.87 & 2.85 & 2.58 & 3.66 & 1.33 & 0.17 \\
\hline eCEC $\left(\mathrm{cmol}_{(+)} \mathbf{k g}^{-1}\right)$ & 8.73 & 7.56 & 11.98 & 13.60 & 6.18 & 7.87 & 29.81 \\
\hline Al Saturation (\%) & 75.80 & 90.82 & 23.79 & 18.96 & 59.24 & 16.93 & 0.58 \\
\hline
\end{tabular}

Regarding heavy metals, no significant differences were found as a function of depth, which allowed overall interpretation of data as a whole.

Total Fe was between 19000 and $35000 \mathrm{mg} \mathrm{kg}^{-1}$ in pastureland soils, and between 28000 and $38000 \mathrm{mg} \mathrm{kg}^{-1}$ in forest soils (Figure 1), thus within the range indicated by Fernández and Carballeira (2001) for the surface layer of soils in NW Galicia (5941-45858 mg kg-1).
Total Mn was between 120-472 $\mathrm{mg} \mathrm{kg}^{-1}$ in pastureland soils, and between $337-516 \mathrm{mg} \mathrm{kg}^{-1}$ in forest soils (Figure 1), with the highest levels corresponding to both natural soils and to the pasturelands P4 and P5; furthermore, SN1 and $\mathrm{P} 5$ are well above the reference $\mathrm{Mn}$ levels for soils over quartzite (197 $\mathrm{mg} \mathrm{kg}^{-1}$ ), and SN2 and $\mathrm{P} 4$ well above that corresponding to slate (346 $\mathrm{mg} \mathrm{kg}^{-1}$ ) (Macías and Calvo 2008); however all these were lower levels than that reported by 
Franco-Uría et al. (2009) for pasturelands in A Pastoriza (average $659 \mathrm{mg} \mathrm{kg}^{-1}$ ), and are well below the phytotoxic limit (1500-3000 $\left.\mathrm{mg} \mathrm{kg}^{-1}\right)$ indicated by Kabata-Pendias and Pendias (1992).

Total Cu was between $0.1-24 \mathrm{mg} \mathrm{kg}^{-1}$ in pastureland soils, and between $8-55 \mathrm{mg} \mathrm{kg}^{-1}$ in forest soils (Figure 1). Soils over quartzite (SN1, P1, P2, P3 and $\mathrm{P} 5$ ) had $\mathrm{Cu}$ concentrations generally lower than the background reference $\left(16.8 \mathrm{mg} \mathrm{kg}^{-1}\right.$, Macías and Calvo 2008), whereas soil SN2 (over slate) overpassed the reference background concentration $\left(24.9 \mathrm{mg} \mathrm{kg}^{-1}\right)$, with higher levels at the highest depth. López-Mosquera et al. (2005) found $23 \mathrm{mg} \mathrm{kg}^{-1}$ as average total Cu concentration for Galician pasturelands, while Franco-Uría et al. (2009) detected $20.5 \mathrm{mg} \mathrm{kg}^{-1}$ as average total $\mathrm{Cu}$ levels in A Pastoriza pasturelands, near that corresponding to our P4 and P5 pastureland soils, but lower to that of our SN2 forest soil. Kabata-Pendias and Pendias (1992) considered as phytotoxic total $\mathrm{Cu}$ concentrations between 60-100 mg kg-1, which were not reached by any of the soil samples analyzed in the present study. Hashim et al. (2011) indicate that total Cu concentrations between $30-100 \mathrm{mg} \mathrm{kg}^{-1}$ can be considered phytotoxic, values that were not detected in our pastureland soils, but the lower limit was widely overpassed by our forest soil on slate.

Total $\mathrm{Zn}$ was between $18-73 \mathrm{mg} \mathrm{kg}^{-1}$ in pastureland soils, and between $27-48 \mathrm{mg} \mathrm{kg}^{-1}$ in forest soils (Figure 1), with the highest values corresponding to soil P4. These levels are similar to that signaled by Macías and Calvo (2008) as background reference for quartzite and slate (47 and $69 \mathrm{mg} \mathrm{kg}^{-1}$, respectively), but lower than that found by Franco-Uría et al. (2009) in pastureland soils of the same geographic area $\left(98.7 \mathrm{mg} \mathrm{kg}^{-1}\right)$, and to that signaled by López-Mosquera et al. (2005) for Galician pasturelands $\left(66 \mathrm{mg} \mathrm{kg}^{-1}\right)$. Most samples were below the phytotoxic levels indicated by Kabata-Pendias and Pendias (1992) $\left(70-400 \mathrm{mg} \mathrm{kg}^{-1}\right)$, and by Hashim et al. (2011) (400 mg kg-1).

Total As was between 4-19 $\mathrm{mg} \mathrm{kg}^{-1}$ in pastureland soils, and between $6-20 \mathrm{mg} \mathrm{kg}^{-1}$ in forest soils (Figure 2), with the highest levels associated to slate as parent material (concretely, soils SN2 and P4), but always lower that the background reference values indicated by Macías and Calvo (2008): $44.5 \mathrm{mg} \mathrm{kg}^{-1}$ on slate, and $25.1 \mathrm{mg} \mathrm{kg}^{-1}$ on quartzite.

Total Ni was between $2-23 \mathrm{mg} \mathrm{kg}^{-1}$ in pastureland soils, and between $7-22 \mathrm{mg} \mathrm{kg}^{-1}$ in forest soils (Figure 2), with the highest values corresponding to SN2 and P4 (soils over slate), although being lower than the background reference (43.2 and $34.9 \mathrm{mg} \mathrm{kg}^{-1}$, on slate and quartzite, respectively) signaled by Macías and Calvo (2008), and clearly lower that the phytotoxic threshold levels indicated by Kabata-Pendias and Pendias (1992) (100 mg kg-1). Franco-Uría et al. (2009) found average values of $23.5 \mathrm{mg} \mathrm{kg}^{-1}$ in pastureland soils of the same area, and LópezMosquera et al. (2005) detected $27 \mathrm{mg} \mathrm{kg}^{-1}$ as average values for Galician pastureland soils. All our soil samples were below these levels, although P4 was near them.

Total Cr was between $39-95 \mathrm{mg} \mathrm{kg}^{-1}$ in pastureland soils, whereas it was $62-94 \mathrm{mg} \mathrm{kg}^{-1}$ in forest soils, with increasing levels as a function of depth (Figure 2). Pastureland soils P1, P2, P3 and P5, as well as the forest soil SN1 had $\mathrm{Cr}$ concentrations above the background reference for soils over quartzite $\left(28.3 \mathrm{mg} \mathrm{kg}^{-1}\right.$, Macías and Calvo 2008), with soils P4 and SN2 showing similar levels to the background for soils over slate $\left(85 \mathrm{mg} \mathrm{kg}^{-1}\right)$. Our values were above those previously found by Franco-Uría et al. (2009) in the area $\left(54.1 \mathrm{mg} \mathrm{kg}^{-1}\right)$, and the average for Galician pasturelands (44 mg kg ${ }^{-1}$, LópezMosquera et al. 2005), although being lower than the phytotoxic levels $\left(75-100 \mathrm{mg} \mathrm{kg}^{-1}\right)$ indicated by Kabata-Pendias and Pendias (1992).

Total $\mathrm{Pb}$ was between $6-18 \mathrm{mg} \mathrm{kg}^{-1}$ in pastureland soils, and between $13-18 \mathrm{mg} \mathrm{kg}^{-1}$ in forest soils (Figure 2). Both natural soils and the pastureland soils P4 and P5 presented the highest levels, although being lower than the background for quartzite (19.2 $\mathrm{mg} \mathrm{kg}^{-1}$ ) and slate $\left(26.1 \mathrm{mg} \mathrm{kg}^{-1}\right)$ soils (Macías and Calvo 2008). Soils P4 and P5, as well as our two forest soils exhibited higher $\mathrm{Pb}$ levels than that previously reported by Franco-Uría et al. (2009) (11.7 $\mathrm{mg} \mathrm{kg}^{-1}$ ) for pasturelands in the 

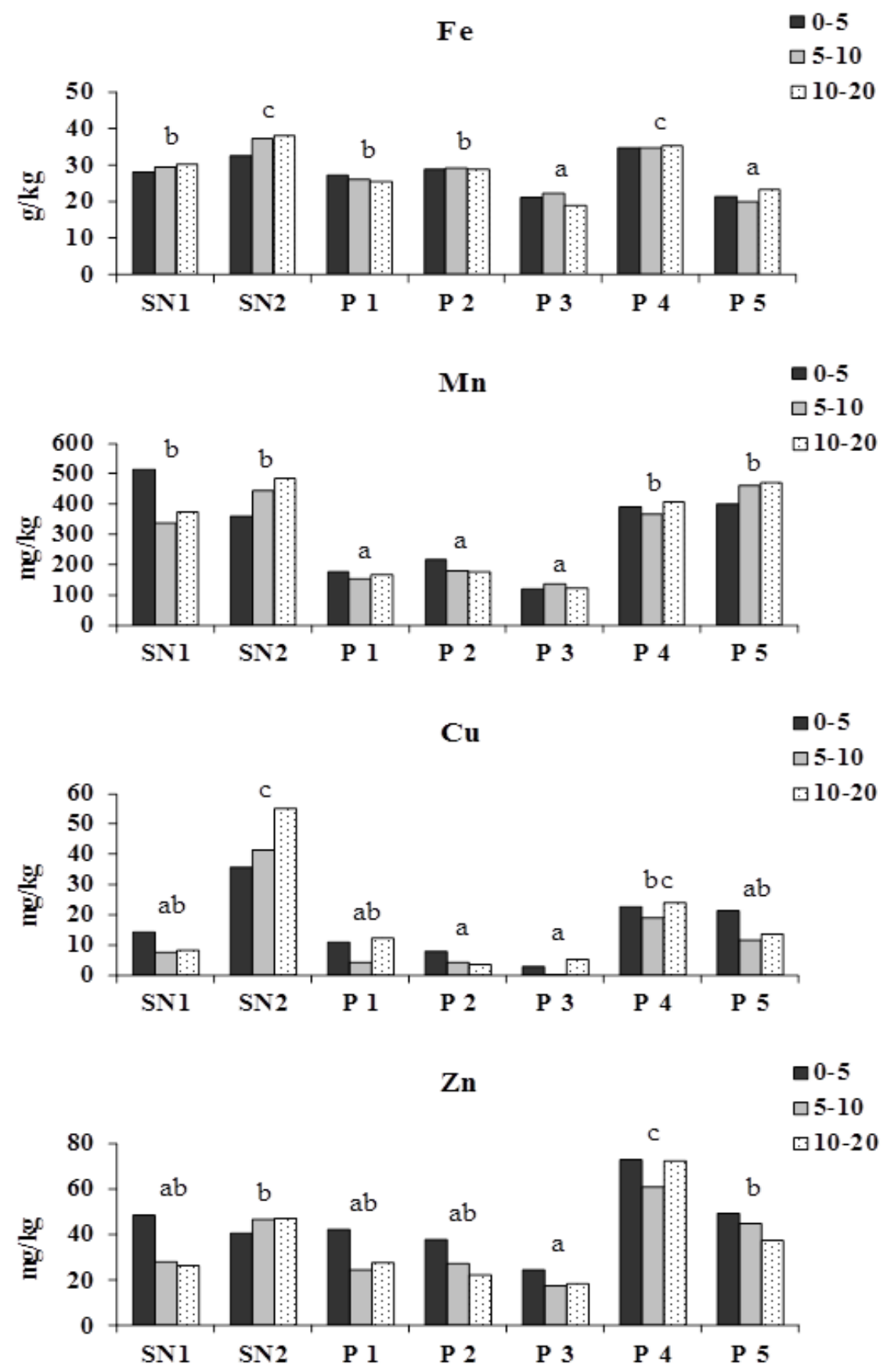

Figure I. Total $\mathrm{Cu}, \mathrm{Fe}, \mathrm{Mn}$ and $\mathrm{Zn}$ concentrations in forest (SN) and pastureland $(\mathrm{P})$ soils at various depths $(0-5,5-10,10-20 \mathrm{~cm})$. Different letters indicate significant differences between samples $(p<0.05)$, considering there is not soil depth influence. 
As
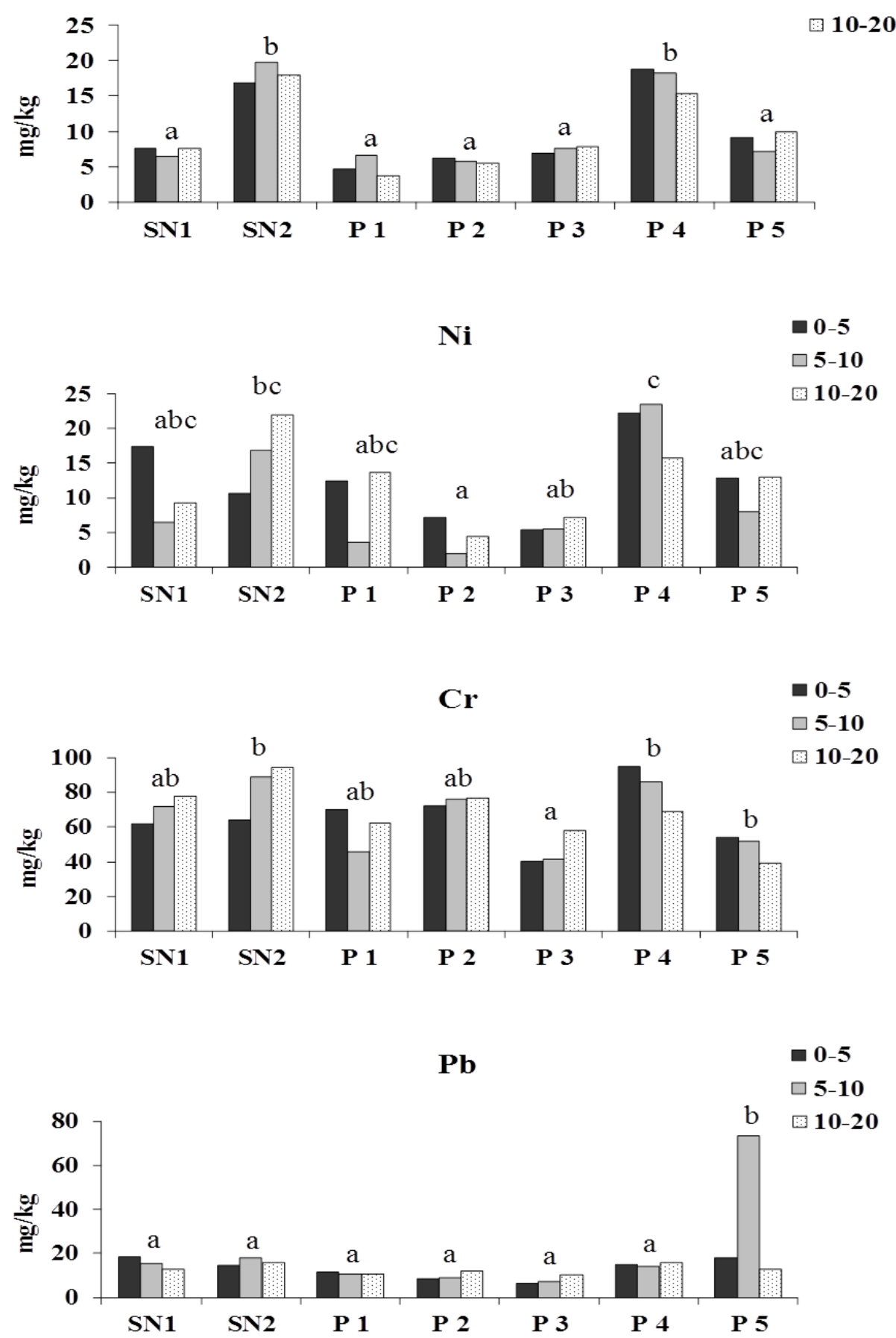

Figure 2. Total $\mathrm{As}, \mathrm{Cr}, \mathrm{Ni}$, and $\mathrm{Pb}$ concentrations in forest $(\mathrm{SN})$ and pastureland $(\mathrm{P})$ soils at various depths $(0-5,5-10,10-20 \mathrm{~cm})$. Different letters indicate significant differences between samples $(p<0.05)$, considering there is not soil depth influence. 
area, and by López-Mosquera et al. (2005) as average for Galician pastureland soils $(12 \mathrm{mg}$ $\left.\mathrm{kg}^{-1}\right)$. Any case, all soil samples showed lower levels than the threshold for phyto-toxicity indicated by Kabata-Pendias and Pendias (1992) $\left(100-400 \mathrm{mg} \mathrm{kg}^{-1}\right)$ and by Hashim et al. (2011) $\left(30-100 \mathrm{mg} \mathrm{kg}^{-1}\right)$.

Cd was not detected in this study.

\section{Discussion}

Heavy metals concentration in soils, as well as its impact on ecosystems depends mainly on the parent material, climate conditions and anthropogenic activities (Khan et al. 2013). In addition, heavy metals can be incorporated to soils by means of pesticides, amendments, inorganic and organic fertilizers (Jia et al. 2010; Moral et al. 2008; Sager 2007; Zhang et al. 2012b). In A Pastoriza, high amounts of cattle slurry and inorganic fertilizers are spread to increase pasture production, which can increase heavy metals pollution (Carballas et al. 1990; Calvo-Rodríguez 2003).

The statistical study of the influence of soil depth $(0-5,5-10$ and $10-20 \mathrm{~cm}$ ), soil use (pastureland and forest), and parent material (quartzite and slate) on the parameters included in Table 1, gave as result that soil use was the only one affecting significantly to some of these parameters. Concretely, forest soils presented significantly lower levels for $\mathrm{pH}_{\mathrm{KCl}}$, total $\mathrm{P}$ and total $\mathrm{Ca}$, in accordance with that expected as consequence of the spreading of amendments and fertilizers on pasturelands, and significantly higher levels for total Al.

Regarding heavy metals concentration, the order was as follows: $\mathrm{Fe}>\mathrm{Mn}>\mathrm{Cr}>\mathrm{Zn}>\mathrm{Pb}$ $\geq \mathrm{Ni} \geq \mathrm{Cu}>\mathrm{As}>\mathrm{Cd}$ (Figures 1 and 2). Analysis of variance indicated that depth did not affect significantly heavy metals concentrations. The
Student's $T$ test showed significantly higher $\mathrm{As}, \mathrm{Cr}, \mathrm{Fe}$ and $\mathrm{Mn}$ levels in forest soils than in pasturelands. Soils SN2 and P4 (over slate) presented significantly higher levels for $\mathrm{Fe}, \mathrm{Cr}$, $\mathrm{Cu}, \mathrm{Mn}, \mathrm{Ni}$ and $\mathrm{Zn}$ than soils over quartzite, which could be due to the frequent association of heavy metals to sulfides and arsenic compounds taking place in slates (Macías and Calvo 2008). Moreover, soil P4 presented significantly higher levels of $\mathrm{Zn}$ than soil SN2 (Figure 1), probably due to cattle slurry spreading (Carballas et al. 1990)

Table 2 shows that heavy metals concentrations correlated by pairs, unless with $\mathrm{Pb}$. Correlations found between As and Fe suggest that As could derive from $\mathrm{FeAsS}$ or from $\mathrm{FeAs}$, which are usually associated to slate. In the case of $\mathrm{Cu}$, it could be associated to $\mathrm{Fe}$ in $\mathrm{CuFeS}_{2}$, whereas $\mathrm{Cr}$ can adsorb on $\mathrm{Fe}$ oxy-hydroxides, and $\mathrm{Ni}$ can be in sulfides as $(\mathrm{Ni}, \mathrm{Fe})_{9} \mathrm{~S}_{8}$, or substituting $\mathrm{Fe}$ (II) in pyrite or other sulfides (Macías and Calvo 2008). There was no significant correlation between heavy metals and $P$, which is an element incorporated to the studied pasturelands both with cattle slurry and with inorganic fertilizers.

Significant correlations between most heavy metals and $\mathrm{Fe}$, as well as the absence of correlation with $\mathrm{P}$ (Table 2) and the fact of finding higher concentrations in soils over slate, and similar values for forest and pastureland soils, all direct towards the existence of a geological origin for most heavy metals in the soils of the area, as previously found by Jia et al. (2010) studying cultivated soils in China. $\mathrm{Cr}$ and $\mathrm{Mn}$ were the only two heavy metals showing higher levels than the background indicated by Macías and Calvo (2008) for Galician soils over the same parent materials, although the importance of fertilization at this regard can be discarded, with forest and pastureland soils presenting similar $\mathrm{Cr}$ and $\mathrm{Mn}$ concentrations. $\mathrm{Zn}$ levels in soil P4 could be in relation with cattle slurry and inorganic fertilizers spreading, being lower to those found by Franco-Uría et al. (2009) in A Pastoriza pasturelands, and similar to that found by López-Mosquera et al. (2005) in Galician pasturelands. 
The pastureland soils studied presented lower levels of heavy metals than the threshold values indicated in the European Commission Directive 86/278/ECC (European Communities 1986, translated to the Galician legislation as Decreto 125/2012 (Anexo VII) de la Comunidad Autónoma de Galicia) referred to sewage sludge application on cultivated soils with $\mathrm{pH}<7$. However, taking into account the new limits proposed for 2015 (European Commission 2000) for soils with $\mathrm{pH}$ $5-6,100 \%$ of our soil samples (including forest soils) are above the limit for $\mathrm{Cr}\left(30 \mathrm{mg} \mathrm{kg}^{-1}\right)$, while our two soils over slate (SN2 and P4) are above limits for $\mathrm{Cu}$ and $\mathrm{Ni}$ (20 and $15 \mathrm{mg} \mathrm{kg}^{-1}$, respectively), and the pastureland soil P4 is above the limit for Zn $\left(60 \mathrm{mg} \mathrm{kg}^{-1}\right)$.

Although heavy metal levels in the area are related mainly to lithology, cattle slurry is spread every year without control, which could give progressive heavy metals accumulation and increasing risks of soil and water pollution, and eventual transfer to the food chain (Dong et al. 2011). In view of that, more careful regulations could be considered to diminish risks of soil and water pollution in such intensive farming areas with remarkable heavy metals lithological contribution.

Table 2. Matrix of correlations between pairs of elements (total concentrations, expressed in $\mathrm{mg} \mathrm{kg}^{-1}, \mathrm{n}=525$ )

\begin{tabular}{|c|c|c|c|c|c|c|c|c|c|c|}
\hline & $P$ & $\mathrm{Al}$ & $\mathrm{Fe}$ & $\mathrm{Mn}$ & $\mathrm{Cu}$ & $\mathrm{Zn}$ & $\mathrm{Ni}$ & $\mathrm{Cr}$ & As & $\mathrm{Pb}$ \\
\hline $\mathbf{P}$ & 1 & & & & & & & & & \\
\hline $\mathrm{Al}$ & 0.05 & 1 & & & & & & & & \\
\hline $\mathrm{Fe}$ & 0.27 & -0.15 & 1 & & & & & & & \\
\hline $\mathrm{Mn}$ & 0.04 & -0.10 & $0.42^{*}$ & 1 & & & & & & \\
\hline $\mathrm{Cu}$ & -0.04 & -0.06 & $0.68^{* \star *}$ & $0.65^{\star \star *}$ & 1 & & & & & \\
\hline $\mathrm{Zn}$ & 0.29 & -0.40 & $0.53^{\star *}$ & $0.67^{* \star *}$ & $0.57^{\star *}$ & 1 & & & & \\
\hline $\mathrm{Ni}$ & 0.26 & -0.21 & $0.61^{* *}$ & $0.67^{* *}$ & $0.73^{* * *}$ & $0.81^{* * *}$ & 1 & & & \\
\hline $\mathrm{Cr}$ & 0.31 & -0.13 & $0.84^{* * *}$ & 0.31 & $0.54^{* *}$ & $0.46^{*}$ & $0.54^{* *}$ & 1 & & \\
\hline As & 0.17 & -0.14 & $0.72^{* \star *}$ & $0.57^{* *}$ & $0.81^{* * *}$ & $0.68^{\star * \star}$ & $074^{* * *}$ & $0.55^{\star *}$ & 1 & \\
\hline $\mathrm{Pb}$ & -0.11 & 0.10 & -0.18 & $0.46^{*}$ & 0.11 & 0.25 & 0.06 & -007 & 0.08 & 1 \\
\hline
\end{tabular}

$\mathrm{p}:{ }^{*}<0.05 ;{ }^{* *}<0.01 ;{ }^{* * *}<0.001$

\section{Conclusions}

In the pastureland soils here studied, most heavy metals (As, $\mathrm{Cu}, \mathrm{Fe}$ and $\mathrm{Ni}$ ) concentrations are in relation with the parent geological material, with higher levels in soils over slate and significant correlations with $\mathrm{Fe}$, suggesting pyritic origin. Forest soils show similar or even higher heavy metal concentrations than pastureland soils, although being always lower than the generic threshold levels considered for each parent material. Only $\mathrm{Cr}$ and $\mathrm{Mn}$ show some levels that can be higher than the generic for this kind of soils, although pastureland fertilization do not seem to be the cause, due to the fact that forest soils exhibit similar or even higher 
concentrations. Zn levels in the P4 pastureland soil can be in relation with cattle slurry application, in view of being significantly higher than that found in the SN2 forest soil, developed over the same parent material. All samples show lower heavy metals levels than that established in current sewage sludge spreading regulations; however, taken into consideration the European Commission proposed levels for 2015, Cr would be limiting for slurry spreading in all the studied soils, whereas this would be the case for $\mathrm{Cu}$ and $\mathrm{Ni}$ in soils $\mathrm{SN} 2$ and $\mathrm{P} 4$, and for $\mathrm{Zn}$ in soil $P 4$. Bearing in mind that the detected levels are in relation with natural lithological aspects, these results put in evidence the existence of clear repercussions on the management of the studied soils. To diminish risks of soil and water pollution, as well as transfer to the food chain, it would be necessary to carry out periodical determination of heavy metals concentrations in soils characterized by high natural heavy metal contents and intensive agriculture, which could even lead to improve cattle slurry and inorganic fertilizers spreading regulations.

\section{Acknowledgments}

This work was funded by the Spanish Ministerio de Economía y Competitividad (Grant Reference: CGL2012-36805-C02-01).

\section{REFERENCES}

- Álvarez E, Fernández-Sanjurjo MJ, Seco N, Núñez A. 2012. Use of Mussel Shells as a Soil Amendment: Effects on Bulk and Rhizosphere Soil and Pasture Production. Pedosphere 22:152-164.

- Álvarez E, Viadé A, Fernández-Marcos ML, HernándezNistal J. 2010. Limestone particle size and liming scheduling influence soil properties and pasture production. Soil Sci. 175:601-613.

- Buol SW, Sánchez PQ, Cate RB, Granger MA. 1975. Soil fertility capability classification for fertility management. In: Bornemisza E, Alvarado A, editors. Soil Management in Tropical America. North Carolina State: Raleigh. p. 126-141.

- Calvo-Rodríguez F. 2003. Caracterización dos puríns de vacuno das explotacións da conca do río Magdalena (A Pastoriza). Trabajo Fin de Carrera. Universidad de Santiago de Compostela.

- Carballas T, Díaz-Fierros F, Acea MJ, Cabaneiro A, Carballas M, Gil F, Leirós MC, López E, Núñez A, Villar MC. 1990. El purín de vacuno en Galicia: caracterización, poder fertilizante y problemas ambientales. Santiago de Compostela: Xunta de Galicia.

- Chen HM, Zheng CR, Tu C, Zhu YG. 1999. Heavy metal pollution in soils in China: status and countermeasures. Ambio 28:130-134.

- Decreto 125/2012, de 10 de mayo, por el que se regula la utilización de lodos de depuradora en el ámbito del sector agrario en la Comunidad Autónoma de Galicia. DOGA № 107: 21694-21745. [Internet]. [cited 2014 october 1]. Available from: http://www.xunta.es/dog/Publicados/2012/20120606/ AnuncioC3C1-300512-0002_es.html.

- Dieter HH, Bayer TA, Multhaup G. 2005. Environmental copper and manganese in the pathophysiology of neurologic diseases (Alzheimer's disease and Manganism). Acta Hydroch Hydrob. 33:72-78.

- Dong J, Yang QW, Sun LN, Zeng Q, Liu SJ, Pan J. 2011. Assessing the concentration and potential dietary risk of heavy metals in vegetables at a $\mathrm{Pb} / \mathrm{Zn}$ mine site, China. Environ Earth Sci. 64:1317-1321.

- European Commission. 2000. Working Document on Sludge-3rd draft. Reference ENV.E.S/LM Brussels Belgium. [Internet]. [cited 2014 Oct 1]. Available from: http://ec.europa.eu/environment/waste/sludge/pdf/ sludge en.pdf.

- European Communities. 1986. Council Directive on the protection of the environment and in particular of the soil when sewage sludge is used in agriculture (86/278/EEC). Official Journal of the European Communities L181, 6-12. Brussels. 
- Facchinelli A, Sacchi E, Mallen L. 2001. Multivariate statistical and GIS-based approach to identify heavy metal sources in soils. Environ Pollut. 114:313-324.

- Fernández JA, Carballeira A. 2001. A comparison of indigenous mosses and topsoils for use in monitoring atmospheric heavy metal deposition in Galicia (northwest Spain). Environ Pollut. 114:431-441.

- Franco-Uría A, López-Mateo C, Roca E, FernándezMarcos ML. 2009. Source identification of heavy metals in pastureland by multivariate analysis in NW Spain. J Hazard Mater. 165:1008-1015.

- Guitián F, Carballas T. 1976. Técnicas de análisis de suelos. Santiago de Compostela: Pico Sacro.

- Hashim MA, Soumyadeep-Mukhopadhyay JNS, Sengupta B. 2011. Remediation technologies for heavy metal contaminated groundwater. Review. J Environ Manage. 92:2355-2388.

- IGE. 2012. Instituto Galego de Estadística. [Internet]. [cited 2014 october 1]. Available from: http://www.ige.eu/ web/index.jsp?idioma=es.

- Jia L, Wang W, Li Y, Yang L. 2010. Heavy metals in soil and cops of an intensively farmed area: A case study in Yucheng City, Shandong Province, China. Environ Res Public Health 7:395-412.

- Kabata-Pendias A, Pendias H. 1992. Trace elements in soils and plants. Boca Raton, Florida: CRC Press Inc.

- Khan K, Lu Y, Khan H, Ishtiaq M, Khan S, Waqas M, Wei L, Wang T. 2013. Heavy metals in agricultural soils and crops and their health risks in Swat District, northern Pakistan. Food Chem Toxicol. 58:449-458.

- Khan S, Rehman S, Khan AZ, Khan MA, Shah MT. 2010. Soil and vegetables enrichment with heavy metals from geological sources in Gilgit, northern Pakistan. Ecotoxicol Environ Saf. 73:1820-1827.

- López-Mosquera ME, Barros R, Sainz MJ, Carral E, Seoane S. 2005. Metal concentrations in agricultural and forestry soils in northwest Spain: implications for disposal of organic wastes on acid soils. Soil Use Manag. 21:298305.

- Macías F, Calvo de Anta R. 2008. Niveles genéricos de referencia de metales pesados y otros elementos traza en los suelos de Galicia. Santiago de Compostela: Xunta de Galicia.

- Moral R, Pérez-Murcia MD, Pérez-Espinosa A, MorenoCaselles J, Paredes C, Rufete B. 2008. Salinity, organic content, micronutrients and heavy metals in pig slurries from South-eastern Spain. Waste Manag. 28:367-371.

- Mosquera MR, González-Rodríguez A, RigueiroRodríguez A. 2000. Sward quality affected by different grazing pressures on dairy systems. J Range Manage. 53:603-610.
- Muhammad S, Shah MT, Khan S. 2011. Health risk assessment of heavy metals and their source apportionment in drinking water of Kohistan region, northern Pakistan. Microchem J. 98:334-343.

- Nordberg G, Jin T, Bernard A, Fierens S, Buche JP, Ye T, Kong Q, Wang H. 2002. Low bone density and renal dysfunction following environmental cadmium exposure in China. Ambio 31:478-481.

- Olsen SR, Sommers LE. 1982. Phosphorus. In: Page AL, Miller RH, Keeney DR, editors. Methods of Soil Analysis Part 2. Chemical and Microbiological Properties. Madison: ASA \& SSSA. p. 403-430.

- Oves M, Khan MS, Zaidi A, Ahmad E. 2012. Soil contamination, nutritive value, and human health risk assessment of heavy metals: an overview. In: Zaidi A, Wani PA, Khan MS, editors. Toxicity of Heavy Metals to Legumes and Bioremediation. New York: Springer. $p$. 1-27.

- Peech L, Alexander LT, Dean LA. 1946. Methods of soil analysis for soil fertility investigations. USDA Cir. № 757.

- Sager M. 2007. Trace and nutrient elements in manure, dung and compost samples in Austria. Soil Biol Biochem. 39:1383-1390.

- Solgi E, Esmaili-Sari A, Riyahi-Bakhtiari A, Hadipour M. 2012. Soil contamination of metals in the three industrial estates, Arak, Iran. Bull Environ Contam Toxicol. 88:634638.

- Sun C, Bi C, Chen Z, Wang D, Zhang C, Sun Y, Yu Z, Zhou D. 2010. Assessment on environmental quality of heavy metals in agricultural soils of Chongming Island, Shanghai City. J Geogr Sci. 20:135-147.

- Turkdogan MK, Fevzi K, Kazim K, llyas T, Ismail U. 2003. Heavy metals in soil, vegetables and fruits in the endemic upper gastrointestinal cancer region of Turkey. Environ Toxicol Pharmacol. 13:175-179.

- WRB. 2006. Word Soil Resources Reports No. 103. Roma: FAO.

- Zhang F, Li Y, Yang M, Li W. 2012b. Content of Heavy Metals in Animal Feeds and Manures from. Farms of Different Scales in Northeast China. Int J Environ Res Public Health. 9:2658-2668.

- Zhang XW, Yang LS, Li YH, Li HR, Wang WY, Ye BX. 2012a. Impacts of lead/zinc mining and smelting on the environment and human health in China. Environ Monit Assess. 184:2261-2273.

- Żukowska J, Biziuk M. 2008. Methodological evaluation of method for dietary heavy metal intake. J Food Sci. $00: R 1-R 9$ 